Egypt. Acad. J. Biolog. Sci., 13(2):129-140 (2020)

Egyptian Academic Journal of Biological Sciences

A. Entomology

ISSN 1687- 8809

http://eajbsa.journals.ekb.eg/

\title{
Biomarkers Changes Induced in The Mediterranean Fruit Fly, Ceratitis capitata (Wied.) Irradiated by Sterilising And Substerilising Doses of Gamma Radiation
}

\author{
R.M. Sayed, R.S. Abdalla, T.S. El Sayed*\& S.A. Rizk. \\ Natural Products Research Department, National Centre for Radiation Research and \\ Technology, Atomic Energy Authority, Cairo, Egypt. \\ Email: rehab.omar@yahoo.com -ragaasaid99@yahoo.com- taamy2010@yahoo.com
}

\begin{abstract}
ARTICLE INFO
Article History

Received:15/3/2020

Accepted:27/4/2020

Keywords:

Mediterranean

fruit fly, gamma

radiation,

substerile, DNA,

RAPD-PCR,

bands.

Radiation technology is widely used to produce changes in biosystems. The goal of this work is to determine the variation induced in male parents and F1 Ceratitiis capitata when gamma-irradiated as pupae using substerilising doses $(50$ and 70 Gy and sterilising dose $90 \mathrm{~Gy}$. Biological studies showed that the percent adult emergence of irradiated pupae decreased as the dose increased and also the percent egg hatchability decreased as the dose increased, also percent pupation and percent emergence of $\mathrm{F} 1$ decreased as the dose increased. Comparing DNA (using RAPD-PCR) of untreated adults, adults irradiated with sterilising dose of 90 Gy and parents irradiated with substerile dose (50 and $70 \mathrm{~Gy})$ and their resultant F1. The results revealed that some extra bands appeared and others disappeared, as a result of irradiation. The appearance of extra bands may be due to the repair mechanism of the irradiation damaged DNA. The banding patterns obtained and the dendrograms drawn on the basis of presence and absence of bands revealed that irradiation of parents with 50 and 70 Gy and their F1 are different from the unirradiated pupae It was concluded that the sterile male technique could be used as a benefit tool in controlling Ceratitiis capitata.
\end{abstract}

\section{INTRODUCTION}

The Mediterranean fruit fly, Ceratitis capitata is considered a major pest of fruit production worldwide. It is a highly polyphagous species with the capability to adapt and spread into several different environments, giving it the status of a threating invasive species for fruit production in many countries (Figueroa 2018).

Management of Ceratitis capitata using traditional chemicals have limited success, and many alternative approaches have been developed and evaluated, including the use of radiation to induce dominant lethal mutations in the sterile insect technique (SIT), it is a major component of many large and successful programmes for pest suppression and eradication. The determination of the appropriate dose of radiation that produces the required level of sterility without impairing the overall fitness of the released insect is very important (Robinson 2002).

Substitutional, eco-friendly methods to control insect pests include the SIT, or the partial male sterility technique (also called inherited sterility IS or F1 sterility). In SIT and Fl sterility, mass production and release of large numbers of genetically altered sterile males are released into the treated area in quantities that surpass the estimated population size of wild

Citation: Egypt. Acad. J. Biolog. Sci. (A. Entomology) Vol. 13(2) pp: 129-140(2020) 
males (also called the critical flooding ratio). The sterile males outcompete the local wild males, and their mating with the females results in non-viable embryos (using SIT) or sterile, highly male-biased offspring (using IS) (Carpenter et al. 2005). The advantages of using IS were previously studied by North (1975) \& La Chance (1985), they described several attributes that are common to IS in Lepidoptera: it is species-specific; has no off-target effects on the environment or on human health, F1 male and female offspring are more sterile than the irradiated parental (P1) generation, and more F1 male progeny than female progeny are produced. Other attributes may include longer developmental time and reduced sperm quality in the F1 generation.

Radiation-induced deleterious effects can be inherited for several generations; however, the majority of the inherited deleterious effects are expressed in the F1 generation. Tothová \& Marec (2001) declared that transmission of various complexes of chromosome translocations is responsible for the production of genetically unbalanced gametes in F1 progeny of treated males and, as such, represent the main chromosomal mechanism of IS.

For the successful use of the SIT in Ceratitis capitata control is that the doses of gamma irradiation do not affect or have less effect on the biology and mating ability of irradiated insects. Full sterility may not be the most favourable condition for a programme, and thus process optimisation is necessary to determining the sterilising dose of gamma irradiation which can be used for minimising somatic damage and maximising male competitiveness. (Abdel-Hamid 2013)

Insect sterilisation through induction of dominant lethal mutation in the genetic material results from the exposure to ionising radiation (IR) (Kinipling 1955). A major source of the mutation load in living organisms is the oxidative DNA damages, with more than 100 oxidative DNA adducts (Von Sonttag 1987).

Recently, several selective and sensitive assays developed, such as restriction fragment length polymorphism, quantitative traits loci, random amplified polymorphic DNA (RAPD), amplified fragment length polymorphisms, simple sequence repeat, a variable number of tandem repeats for DNA analysis in eco-genotoxicology as a result of the advances in molecular biology. RAPD-PCR is one of the most feasible methods or techniques used for the detection of DNA damage and mutations comparing DNA fingerprints from untreated and treated samples (Enan 2006, Lanzone et al. 2016).

The sterile insect male (SIM) is the most widely applied against tephritid fruit flies (Enkerlin 2005). The prosperity of SIM as a pest control method has resulted from its species-specificity and can be used in integration with other control methods. In addition, released gamma- sterilized males are mobile and would actively compete with normal males (Hendrichs et al. 2007).

The random amplified polymorphic DNA (RAPD) assay based on PCR, developed by Williams et al. (1990), amplifies random DNA fragments with short primers of an arbitrary nucleotide sequence. This technique has been reported as an effective method for species classification, genetic mapping, and phylogeny studies. Since the random amplified polymorphic DNA has been used as a powerful tool for detecting DNA damage and mutations (Savva 1998; Atienzar et al. 2001; Ercan 2015). Therefore, any change can be related to the induced sterility and can be used as a bio-indicator for sterility in the mass rearing of Ceratitis capitata for sterile male release and inherited sterility.

The intent of this study was to find a genetic marker made by comparing the alteration in the DNA patterns of a normal and irradiated adult male with sterilising and substerilising dose which would serve as sterility fingerprint and to study the inheritance of sterility to F1. 


\section{MATERIALS AND METHODS}

\section{Rearing and Irradiation Technique:}

The original colony of Ceratitis capitata was obtained from Plant Protection Research Institute; Agricultural Research Center (ARC), Giza, Egypt. The insect was reared under laboratory conditions of $25 \pm 2^{\circ} \mathrm{C}$ and $60 \pm 5 \%$ relative humidity at Natural Products Department, National Center for Radiation Research and Technology. Full-grown pupae (50 pupae) were irradiated with substerilising and sterilising doses of gamma radiation $(50,70$

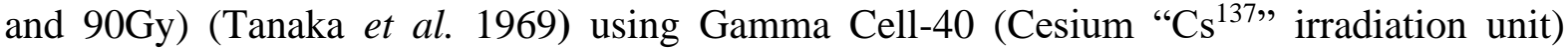
located at National Center for Radiation Research and Technology (NCRRT), Atomic Energy Authority, Egypt. The dose rate of the cell was $0.685 \mathrm{rad} / \mathrm{sec}$.

The number of emerged flies was recorded and the percentage of adult emergence was calculated. To estimate the changes in the biological aspects of the first generation, three replicates for each dose were made, each replicate containing one pair of irradiated males and normal females. Normal (unirradiated) males were used in the control group.

The \% of hatchability was calculated by El-Shazly's (1993) equation, and \% of sterility was determined according to Tappozada et al. (1966).

$$
\begin{aligned}
& \text { Hatchability } \%=\frac{\text { No.of hatehed eggs }}{\text { No.of eggs laid }} \times 100 \\
& \text { Sterility } \left.\%=100-\left(\frac{a * b}{A * B}\right) \times 100\right)
\end{aligned}
$$

Where: a: No. of eggs/female in treatment. b: $\%$ hatchability in treatment.

A: No. of eggs/female in control. B: $\%$ hatchability in control.

The stage duration (larvae and pupae) and the percent emergence of F1 adults were also documented.

\section{DNA Extraction and RAPD-PCR Assay:}

Total body tissue samples were ground with liquid nitrogen using a mortar and pestle. Extraction and purification of samples were carried out with the use of DNeasy mini spin columns as described by the manufacturer (Qiagene, Hilden, Germany) stored at $-80{ }^{\circ} \mathrm{C}$. RAPD-PCR reactions were performed according to the protocol of Williams et al. (1990). Reactions were performed in a total volume $50 \mu \mathrm{l}$ reaction buffer $(100 \mathrm{mM} \mathrm{KCL}$, Tris HCL pH 8.3), $3 \mathrm{mM} \mathrm{MgCl} 2,200 \mathrm{mM}$ dNTPs (Promega Biotech. Inc.), $50 \mathrm{p} / \mathrm{mole}$ primers and $1 \mu \mathrm{l}$ Taq polymerase (obtained from Operon Technologies). This reaction was added to $0.1 \mu \mathrm{l}$ genomic DNA. Tubes containing mixes were placed in a thermocycler (Perkin Elmer 2400) and the DNA was amplified using the following temperature profile (modified from Black et $a l, 1992)$. Ten arbitrary primers were used, four of them only gave polymorphism with the samples (Table 1). Amplification was carried out for 30 cycles. The temperature profiles were $94{ }^{\circ} \mathrm{C}$ for $5 \mathrm{~min}, 94{ }^{\circ} \mathrm{C}$ for $40 \mathrm{sec}, 72{ }^{\circ} \mathrm{C}$ for $2 \mathrm{~min}, 72{ }^{\circ} \mathrm{C}$ for $7 \mathrm{~min} 36^{\circ} \mathrm{C}$ for $1 \mathrm{~min}$, and $4{ }^{\circ} \mathrm{C}$ for hold. After the reaction, the mixture was mixed with DNA loading buffer and electrophoresed on $1 \%$ agarose gel. DNA ladder mix was used as standard DNA with molecular sizes of 2500, 2000, 1500, 1000, 900, 800, 700, 600, 500, 400, 300, 200 and $100 \mathrm{bp}$.

Table 1. List of the primer names and their nucleotide sequences used in the study for RAPD procedure.

\begin{tabular}{|c|c|c|}
\hline & $\begin{array}{c}\text { Primer } \\
\text { name }\end{array}$ & Sequence \\
\hline 1 & OP-A7 & 5' GAA AGG GGT G 3' \\
\hline 2 & OP-B2 & $5^{\prime}$ TCG GGG ATA G 3' \\
\hline 3 & OP-B11 & 5' GTA GAC CCG T 3' \\
\hline 4 & OP-C2 & 5' GGG GGT CTT T 3' \\
\hline 5 & OP-C4 & 5' CCG CAT CTA C 3' \\
\hline 6 & OP-D1 & 5 ACC GCG AAG G 3' \\
\hline
\end{tabular}




\section{Data Analysis:}

The data were statistically evaluated by analysis of variance $(F)$ followed by Tukey Pairwise Comparisons test to examine the significant differences between the treatments. The statistical Minitab program was used for all analyses.

\section{RESULTS}

\section{Biological Studies;}

When full grown pupae irradiated with sub sterilising doses of 50 and 70 Gy and sterilising dose of $90 \mathrm{~Gy}$. The percent of adult emergence was 78.67, 46.67 and18\% respectively compared to $99.33 \%$ in unirradiated control (Table 2). Also, Table 2 shows the percent of F1 adult emergence which were 56.67 and 20 for 50 and 70 Gy respectively. Statistical analysis showed significant differences in parents and in F1.

Table 2. Effect of gamma radiation on percent emergence of parents irradiated as full grown pupae.

\begin{tabular}{|c|c|c|}
\hline Doses (Gy) & Parent adult emergence (\%) & F1 adult emergence (\%) \\
\hline 0 & $99.33 \pm 0.67^{\mathrm{A}}$ & $98.67 \pm 0.67^{\mathrm{A}}$ \\
\hline 50 & $78.67 \pm 0.67^{\mathrm{B}}$ & $56.67 \pm 2.4^{\mathrm{B}}$ \\
\hline 70 & $46.67 \pm 1.76^{\mathrm{C}}$ & $20 \pm 2.3^{\mathrm{C}}$ \\
\hline 90 & $18 \pm 1.15^{\mathrm{D}}$ & - \\
\hline
\end{tabular}

- Values represent the mean \pm S.E of 3 replicates (50 pupae).

- Different letter means statistically significant at $P<0.05$ (Tukey Pairwise Comparisons test).

Table 3 shows a decrease in percent hatchability as the dose of gamma radiation increased and it was 71.33 at the dose level of $50 \mathrm{~Gy}$ and reached 0 at $90 \mathrm{~Gy}$ compared to $99.33 \%$ in control. Significant differences were found between all doses.

Percent sterility increased as the dose increased being 0 in control and reached $100 \%$ at the sterilising dose. Significant differences were found between all doses.

Larval duration increased as the dose increased to reach 35 days`compared to 21 days in the control, percent pupation decreased as the dose increased to reach $40 \%$ at $70 \mathrm{~Gy}$ compared to $98.67 \%$ in the control, pupal duration also increased as the dose increased to reach 21.67 days at 70 Gy compared to 9.33 days in the control. Significant differences were found between all doses in larval duration, \% pupation, and pupal duration.

Table 3. Effect of gamma radiation on percent hatchability, percent pupation and percent emergence of F1producing from parents irradiated as full-grown pupae.

\begin{tabular}{|c|c|c|c|c|c|}
\hline $\begin{array}{c}\text { Doses } \\
\text { (Gy) }\end{array}$ & $\begin{array}{c}\text { Hatchability } \\
(\mathbf{\%})\end{array}$ & Sterility (\%) & $\begin{array}{c}\text { Larval } \\
\text { duration } \\
\text { (day) }\end{array}$ & $\begin{array}{c}\text { Pupation } \\
\text { (\%) }\end{array}$ & $\begin{array}{c}\text { Pupal } \\
\text { duration } \\
\text { (day) }\end{array}$ \\
\hline 0 & $99.33 \pm 0.66^{\mathrm{A}}$ & $0 \pm 0^{\mathrm{D}}$ & $21 \pm 1^{\mathrm{C}}$ & $98.67 \pm 0.67^{\mathrm{A}}$ & $9.33 \pm 0.33^{\mathrm{C}}$ \\
\hline 50 & $71.33 \pm 0.66^{\mathrm{B}}$ & $48.4 \pm 0.66^{\mathrm{C}}$ & $28 \pm 1.15^{\mathrm{B}}$ & $64.67 \pm 2.9^{\mathrm{B}}$ & $14 \pm 1^{\mathrm{B}}$ \\
\hline 70 & $36 \pm 1.15^{\mathrm{C}}$ & $86.86 \pm 1.15^{\mathrm{B}}$ & $35 \pm 0^{\mathrm{A}}$ & $40 \pm 1.15^{\mathrm{C}}$ & $21.67 \pm 1.76^{\mathrm{A}}$ \\
\hline 90 & $0 \pm 0^{\mathrm{D}}$ & $100 \pm 0^{\mathrm{A}}$ & - & - & - \\
\hline
\end{tabular}

- Values represent the mean \pm S.E of 3 replicates (50 eggs, 50 larvae and 50 pupae).

- Different letter means statistically significant at $P<0.05$ (Tukey Pairwise Comparisons test).

Table 4 data screen the genomic DNA extracted from unirradiated males (control) and males irradiated with 50, 70 and $90 \mathrm{~Gy}$. Banding patterns for that used six random primers were scored as present (1) or absent (0) according to their molecular sizes revealed that the 
percentage of polymorphism were $25 \%, 20 \%, 50 \%, 25 \%, 50 \%$ and $33.33 \%$ with OP-A7, OPB2, OP-B11, OP-C2, OP-C4, and OP-D1 primers, respectively. The number of produced fragments was 37 distributed as 8, 5, 6, 4, 8 and 6 with OP-A7, OP-B2, OP-B11, OP-C2, OP$\mathrm{C} 4$, and OP-D1 primers, respectively. The molecular size of the fragments ranged from $22601 \mathrm{bp}$ to $145 \mathrm{bp}$. The highest molecular size was detected in OP-C4 and the lowest molecular size was detected by using primer OP-B2. In the present investigation irradiated parent males with sterilising dose (90 Gy) and sub sterilising doses (50 and 70 Gy) were compared to F1 males produced from those irradiated with 50 and 70 Gy and normal ones by analysing the DNA structural changes which might be induced by irradiation and study the inherited sterility to F1 generation.

Table 4. RAPD Finger print profiles were generated by using 10- per primers on genomic DNA from the adults $C$. capitata six random primers OP- A7, OP-B2, OP-B11, OP-C2, OP-C4 and OP-D1.

\begin{tabular}{|c|c|c|c|c|c|c|c|}
\hline d no & $\begin{array}{c}\text { M.wt } \\
\mathrm{Bp}\end{array}$ & Control & P 90 & F1 70 & F1 50 & P70 & P 50 \\
\hline \multicolumn{8}{|c|}{ OP-A7 } \\
\hline 1 & 1830 & 0 & 0 & 1 & 1 & 1 & 1 \\
\hline 2 & 1370 & + & + & + & + & + & + \\
\hline 3 & 830 & 0 & 0 & 1 & 1 & 0 & 0 \\
\hline 4 & 640 & + & + & + & + & + & + \\
\hline 5 & 500 & + & + & + & + & + & + \\
\hline 6 & 425 & + & + & + & + & + & + \\
\hline 7 & 380 & + & + & + & + & + & + \\
\hline 8 & 300 & + & + & + & + & + & + \\
\hline \multicolumn{8}{|c|}{ OP-B2 } \\
\hline 1 & 500 & 1 & 1 & 1 & 1 & 1 & 1 \\
\hline 2 & 415 & 1 & 1 & 1 & 1 & 1 & 1 \\
\hline 3 & 300 & 1 & 1 & 1 & 1 & 1 & 1 \\
\hline 4 & 245 & 1 & 1 & 1 & 1 & 1 & 1 \\
\hline 5 & 145 & 1 & 0 & 0 & 0 & 0 & 0 \\
\hline \multicolumn{8}{|c|}{ OP-Bll } \\
\hline 1 & 1860 & 0 & 0 & 1 & 1 & 0 & 0 \\
\hline 2 & 920 & 0 & 0 & 1 & 1 & 1 & 0 \\
\hline 3 & 630 & 1 & 1 & 1 & 1 & 1 & 1 \\
\hline 4 & 540 & 1 & 1 & 1 & 1 & 1 & 1 \\
\hline 5 & 415 & 0 & 0 & 1 & 1 & 1 & 1 \\
\hline 6 & 385 & 1 & 1 & 1 & 1 & 1 & 1 \\
\hline \multicolumn{8}{|c|}{ OP-C2 } \\
\hline 1 & 1780 & 0 & 0 & 1 & 1 & 1 & 0 \\
\hline 2 & 760 & 1 & 1 & 1 & 1 & 1 & 1 \\
\hline 3 & 560 & 1 & 1 & 1 & 1 & 1 & 1 \\
\hline 4 & 380 & 1 & 1 & 1 & 1 & 1 & 1 \\
\hline \multicolumn{8}{|c|}{ OP-C4 } \\
\hline 1 & 2260 & 0 & 0 & 0 & 1 & 0 & 0 \\
\hline 2 & 1680 & 0 & 0 & 0 & 1 & 0 & 0 \\
\hline 3 & 940 & 1 & 1 & 0 & 1 & 1 & 1 \\
\hline 4 & 685 & 1 & 1 & 1 & 1 & 1 & 1 \\
\hline 5 & 590 & 1 & 1 & 1 & 1 & 1 & 1 \\
\hline 6 & 480 & 1 & 1 & 1 & 1 & 1 & 1 \\
\hline 7 & 445 & 0 & 1 & 1 & 1 & 1 & 1 \\
\hline 8 & 300 & 1 & 1 & 1 & 1 & 1 & 1 \\
\hline OP-D1 & 850 & 0 & 1 & 0 & 0 & 1 & 1 \\
\hline 2 & 635 & 1 & 1 & 0 & 1 & 1 & 1 \\
\hline 3 & 570 & 1 & 1 & 1 & 1 & 1 & 1 \\
\hline 4 & 475 & 1 & 1 & 1 & 1 & 1 & 1 \\
\hline 5 & 325 & 1 & 1 & 1 & 1 & 1 & 1 \\
\hline 6 & 270 & 1 & 1 & 1 & 1 & 1 & 1 \\
\hline
\end{tabular}

Table 5 and Fig 1 illustrate that RAPD markers using primer 1 (OP-A7) indicated the presence of only six common bands in normal and irradiated Ceratitis capitata with sterilising dose of 90 Gy and substerilising doses of 50 and 70 Gy. In F1 and parents respectively, two new bands appeared in F1 irradiated with 50 and 70 Gy and one new band appeared in parents irradiated with 50 and 70 Gy.in comparison to non-radiated control. 
RAPD analysis using primer 2 (OP-B2) indicated the presence of five bands in control, four bands are common and the other unique band disappeared in irradiated samples (parents and F1). RAPD analysis using primer 3 (OP-B11) indicated the presence of three bands in control, the three bands are common and three new bands appeared in parents and in F1, a band with M.W 415 bp appeared in all parents and F1 irradiated with 50 and 70 Gy and band with M.W 1860 bp appeared only in F1 irradiated with 50 and 70 Gy. band with M.W 920 bp appeared in F1 irradiated with 50 and 70 Gy and in parents irradiated with 50 Gy. RAPD analysis using primer 4 (OP-C2) indicated the presence of three bands in control, the three bands are common and the new band appeared in F1 irradiated with 50 and 70 Gy and also in parents irradiated with $50 \mathrm{~Gy}$. RAPD analysis using primer 5 (OP-C4) indicated the presence of five bands in control, four bands are common and the other band disappeared only in F1 irradiated with 70 Gy. Two new bands with M.W (2260 and $1680 \mathrm{bp}$ ) appeared in F1 irradiated with 50 Gy Also new band with M.W 445 bp appeared in all irradiated parents and F1. RAPD analysis using primer 5 (OP-D1) indicated the presence of five bands in control, four bands are common and the other band disappeared only in F1 irradiated with 70 Gy. The new band with M.W 850 bp appeared only in parents irradiated with 50, 70 and 90 Gy.

Table 5. DNA poly morphism using randomly amplifying DNA (RAPD) with six primers for untreated control, parents treated with sterilizing dose, F1 treated with 50 and 70 Gy and parents treated with 50 and 70 Gy in C. capitate

\begin{tabular}{|c|c|c|c|c|c|c|}
\hline The treatments & control & P 90 & F1 70 & F1 50 & P70 & P 50 \\
\hline \multicolumn{7}{|c|}{ OP-A 7} \\
\hline control & 1.0 & & & & & \\
\hline P 90 & 1.0 & 1.0 & & & & \\
\hline F1 70 & 0.86 & 0.86 & 1.0 & & & \\
\hline F1 50 & 0.86 & 0.86 & 1.0 & 1.0 & & \\
\hline P 70 & 0.92 & 0.92 & 0.93 & 0.93 & 1.0 & \\
\hline P 50 & 0.92 & 0.92 & 0.93 & 0.93 & 1.0 & 1.0 \\
\hline \multicolumn{7}{|c|}{ OP-B2 } \\
\hline control & 1.0 & & & & & \\
\hline P 90 & 0.89 & 1.0 & & & & \\
\hline F1 70 & 0.89 & 1.0 & 1.0 & & & \\
\hline F1 50 & 0.89 & 1.0 & 1.0 & 1.0 & & \\
\hline P 70 & 0.89 & 1.0 & 1.0 & 1.0 & 1.0 & \\
\hline P 50 & 1.0 & & & & & \\
\hline \multicolumn{7}{|c|}{ OP-B11 } \\
\hline control & 1.0 & & & & & \\
\hline P 90 & 1.0 & 1.0 & & & & \\
\hline F1 70 & 0.67 & 0.67 & 1.0 & & & \\
\hline F1 50 & 0.67 & 0.67 & 1.0 & 1.0 & & \\
\hline P 70 & 0.75 & 0.75 & 0.91 & 0.91 & 1.0 & \\
\hline P 50 & 0.86 & 0.86 & 0.8 & 0.8 & 0.89 & 1.0 \\
\hline \multicolumn{7}{|c|}{ OP-C2 } \\
\hline control & 1.0 & & & & & \\
\hline P 90 & 1.0 & 1.0 & & & & \\
\hline F1 70 & 0.86 & 0.86 & 1.0 & & & \\
\hline F1 50 & 0.86 & 0.86 & 1.0 & 1.0 & & \\
\hline P 70 & 0.86 & 0.86 & 1.0 & 1.0 & 1.0 & \\
\hline P 50 & 1.0 & 1.0 & 0.86 & 0.86 & 0.86 & 1.0 \\
\hline \multicolumn{7}{|c|}{ OP-C4 } \\
\hline control & 1.0 & & & & & \\
\hline P 90 & 0.91 & 1.0 & & & & \\
\hline F1 70 & 0.8 & 0.91 & 1.0 & & & \\
\hline F1 50 & 0.77 & 0.86 & 0.77 & 1.0 & & \\
\hline P 70 & 0.91 & 1.0 & 0.91 & 0.86 & 1.0 & \\
\hline P 50 & 0.91 & 1.0 & 0.91 & 0.86 & 1.0 & 1.0 \\
\hline \multicolumn{7}{|c|}{ OP-D1 } \\
\hline control & 1.0 & & & & & \\
\hline P 90 & 0.91 & 1.0 & & & & \\
\hline F1 70 & 0.89 & 0.8 & 1.0 & & & \\
\hline F1 50 & 1.0 & 0.91 & 0.89 & 1.0 & & \\
\hline P 70 & 0.91 & 1.0 & 0.8 & 0.91 & 1.0 & \\
\hline P 50 & 0.91 & 1.0 & 0.8 & 0.91 & 1.0 & 1.0 \\
\hline
\end{tabular}




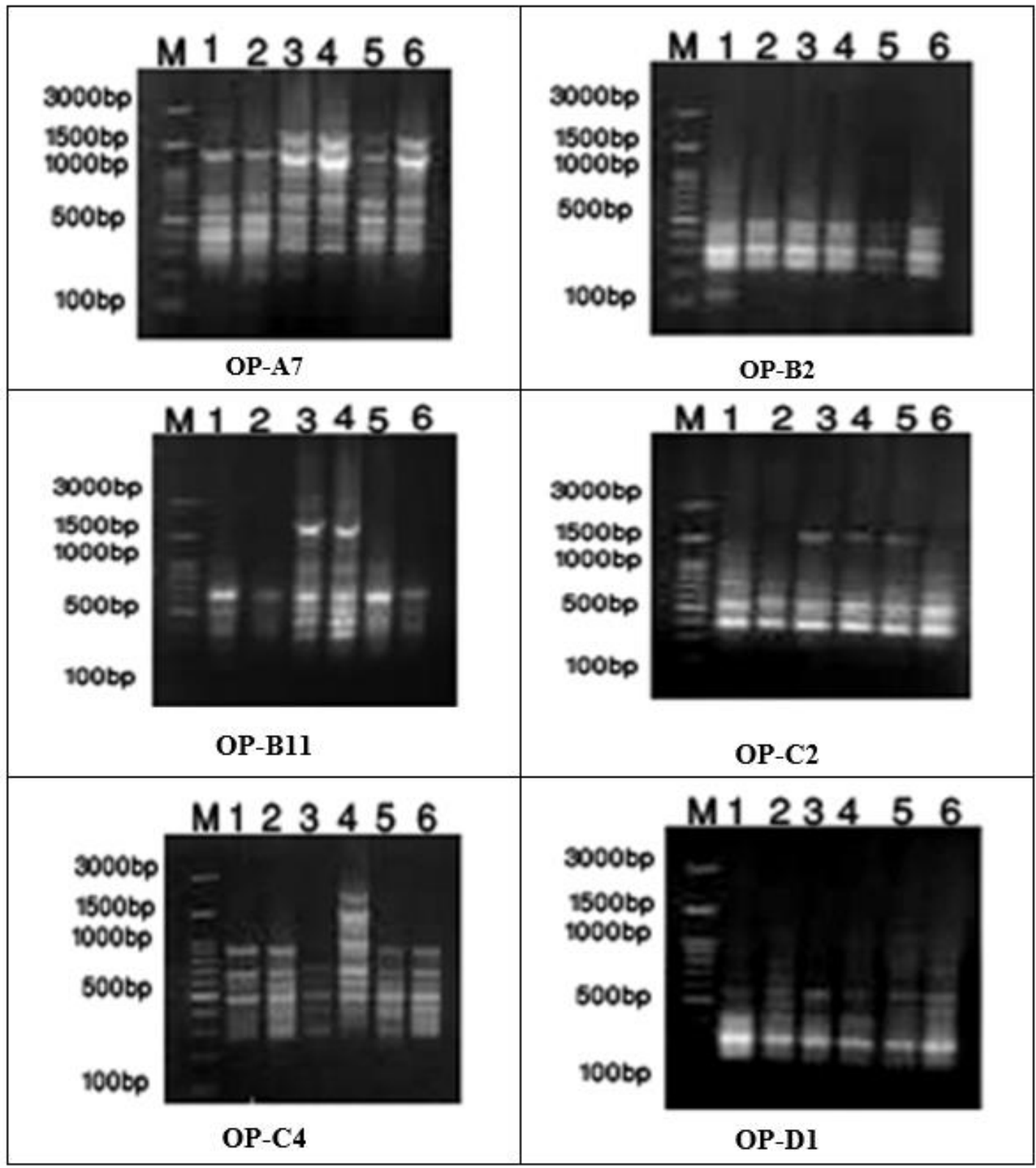

Fig. 1. RAPD-PCR pattern resulting from amplification of genomic DNA C. capitata male in normal, parents irradiated with sterilising dose of $90 \mathrm{~Gy}$ and substerilising doses of 50 and 70 Gy and F1.

$$
\begin{aligned}
& \text { M: marker } \quad \text { 1: Control } \quad 2: \mathrm{P} 90 \mathrm{~Gy} \quad 3: \mathrm{F} 170 \mathrm{~Gy} \\
& \text { 4: F150 Gy 5: P70 Gy 6: P } 50 \text { Gy }
\end{aligned}
$$

Table 6 illustrates that the highest similarity values for the primer OP-A7 were found between (P 90 and the control), also between (F1 70 and F1 50) and (P 50 and P 70).

Using the Primer OP-B2 showed that the highest similarity values were found between( P 50 and control), (F1 70 and P 90), (F1 70 with F1 50), (P 70 with P 90 ) and (F1 50 with P 90), ( P 70 with both F1 50 and F1 70)

Using the Primer OP-B11 showed that the highest similarity values were found between (control with P 90), (F1 70 with F1 50)

Using the Primer OP-C2 showed that the highest similarity values were found between (control with P 90), (P 70 with both F1 50 and F1 70), and finally between (P 50 with control and P 90) 
Using the Primer OP-C4 showed that the highest similarity values were found between (P 90 with both P 50 and P 70) and finally between (P 70 with P 50).

Using the Primer OP-D1 showed that the highest similarity values were found between (F1 50 with control) and between (P 70 with P 90) and finally between (P 50 with both P 70 and $\mathrm{P}$ 90).

Table 6. Similarity index with six primers for untreated control, parents treated with sterilizing dose, F1 treated with 50 and 70 Gy and parents treated with 50 and 70 Gy in C. capitata

\begin{tabular}{|c|c|c|c|c|c|}
\hline $\begin{array}{c}\text { Primer } \\
\text { name }\end{array}$ & $\begin{array}{c}\text { Total } \\
\text {,band }\end{array}$ & $\begin{array}{c}\text { Monomorphic } \\
\text { band }\end{array}$ & $\begin{array}{c}\text { Polymorphic } \\
\text { band }\end{array}$ & $\begin{array}{c}\text { Unique } \\
\text { band }\end{array}$ & $\begin{array}{c}\text { Polymorphic } \\
\%\end{array}$ \\
\hline A7 & 8 & 6 & 2 & - & $25 \%$ \\
\hline B2 & 5 & 4 & 1 & 1 & $20 \%$ \\
\hline B11 & 6 & 3 & 3 & - & $50 \%$ \\
\hline C2 & 4 & 3 & 1 & - & $25 \%$ \\
\hline C4 & 8 & 4 & 4 & 2 & $50 \%$ \\
\hline D1 & 6 & 4 & 2 & - & $33.33 \%$ \\
\hline Total & 37 & 23 & 14 & 5 & $37.83 \%$ \\
\hline
\end{tabular}

On the other hand, the lowest similarity value in OP-A7 was 0.86 and found between both (the control and P 90 with F170 and F1 50) in primer OP-B11. Also, the lowest value in primer OP-B11 was 0.67 which found between both (the control and P 90 with F170 and F1 50). In primer OP-C2, the lowest similarity value was 0.86 between both (the control and $P$ 90 with F1 70, F1 50 and P 70) and also between (P 50 with both F1 70, F1 50 and P70). In primer OP-C4, the lowest value was 0.77 found between (F1 50 and both control and F1 70). Using the Primer OP-D1 showed that the lowest similarity value was 0.8 and found between (P 90 and F1 70) and between (F1 70 and both P 70 and P 50).

\section{DISCUSSION}

Our results show that the exposure of the pupae to gamma radiation caused a reduction in egg hatchability and an increase in \% sterility as the dose increase. These results agree with Ibrahim \& EL-Naggar (2001) on Spodoptera littoralis who stated that the fertility of treated males declined almost linearly to reach $0 \%$ at approximately $400 \mathrm{~Gy}$. irradiation had a positive effect on sterility whereas irradiation dose increased, the sterility increased. The obtained results, showed a decrease in percent emergence of the adult Ceratitis capitata, and percent emergence as the dose of gamma radiation increased, Katiyar \& Valerio (1964) found a margin between doses required to induce sterility and those that cause severe deleterious effects in Ceratitis capitata. Doses ranged from 80-100 Gy induced high levels of sterility while adult emergence from irradiated mature pupae was not significantly affected up to a dose of (200 Gy). When a 4-days-old laboratory and wild strain of pupae were exposed to 60 and $100 \mathrm{~Gy}$ of gamma radiation, adult emergence decreased as compared with the control (Akman \& Zumreoglu, 1978). Hamza (2007) showed that Eumerus amoneus adult emergence was reduced as a result of gamma irradiation to their pupae.

The radiation dose used to induce sterility is of prime importance in programs involving the release of sterile insects. Insects that receive too low a dose are not sufficiently sterile, while those receiving too high a dose may be uncompetitive, which may then require the release of a greater number of sterile insects (Robinson et al. 2002).

The double-strand breaks in DNA double helix are believed to be the most important type of lesion produced in chromosome by ionising radiation, cracking the chromatin into different pieces that may result in cell killing or mutation. Examples of lethal aberrations to 
the cell are the dicentric and ring (which are chromosome aberrations) and the anaphase bridge (a chromatid aberration). Two relevant aberrations that are usually not lethal to the cell are symmetrical translocation and small deletions. These changes and mutations left in the genetic code will influence base pairing, coding, transcription, and gene expression (O'Brien \& Wolfe 1964; Hall \& Giaccia 2006). The study of the RAPD-PCR profiles of normal and irradiated males as pupae Ceratitis capitata and their F1 showed variation between them. The appearance of some extra bands and the disappearance of others, as a result of irradiation, were recorded throughout this study causing variations in the PCR patterns among different samples. These induced variations differ according to the dose of irradiation given and differ from non-irradiated males and males irradiated as pupae. These results agree with those of Lea (1956) who stated that ionising radiations deposits energy in an absorber at discrete loci randomly distributed within the radiation field and that ionization which occurs in the cellular structure depends on the dose of radiation and on target size. In this study, the RAPD- PCR profile of some irradiated samples, revealed the appearance of some extra fragments and the disappearance of one or more fragments. Similar findings were recorded by Alexandrov et al. (1998) who stated that $62.5 \%$ of the gamma rays induced mutants revealed a deficiency of one or more fragments produced, the rest of mutants showed no alterations in the PCR patterns indicating possible small scale changes (point mutations) inside the gene region studies or the gross lesion probably situated. Similar results on Callosobruchus maculatus were also obtained by Zaghloul et al. (2006). Alterations in DNA patterns of the sterile males provide an explanation for the induced sterility and augment the importance of the DNA in the transfer of genetic materials from cell to cell. However, the similarity in DNA patterns of a normal and irradiated adult was interpreted by supposing that radiation-induced damages in regions of the genome other than at the loci under study. Changes between parents and F1 in the number of bands was also studied by El-Sayed (2013) on her study on $S$. littoralis males (emerged from irradiated pupae) at various generations (parents, F1 and F2) showed variation between them. The appearance of extra bands and disappearance of others, as a result of irradiation, were recorded throughout the investigation causing the variations in the PCR pattern among the different samples although they are belonging to the same generation. The variations in the PCR patterns depend on the primer used, the dose of gamma irradiation given to the insect, the kind of the irradiation source and differ from the parent, F1 and F2 Rizk et al. (2017) stated that the effects of $\gamma$ rays on the DNA patterns of adult male parents and F1 males Galleria melonella showed alterations among the controls, the treated parents and F1 individuals. Exposure to radiation caused very frequently the appearance of some extra bands and the deficiency of others in the arbitrary random amplified polymorphic DNA-polymerase chain reaction amplification patterns of the irradiated insects also Zahran et al. (2017) Full-grown male pupae of the peach or guava fruit fly, Bactrocera zonata were irradiated with sterilizing and substerilising doses of gamma radiation. The effect of gamma rays on the DNA patterns of adult males showed alterations from the control. Exposure to radiation caused very frequently the appearance of some extra bands and the deficiency of others in the RAPD-PCR amplification patterns of the irradiated insects

\section{REFERENCES}

Abbott, W.S. 1925. A method of computing the effectiveness of an insecticide. J. of Econ. Entomol. 18: 265-267.

Abdel-Hamid, W. A. 2013. Effect of gamma irradiation on Mediterranean fruit fly, Ceratitis capitata (Wiedemann) and improvement of the sterile insect technique. Ph.D. thesis, Faculty of Agriculture, Cairo University, Cairo, 
Afia, Y. E. 2007. Comparative studies on the biological and ecological of the two fruit flies, in Egypt, Bactrocera zonata and Ceratitis capitata. Ph.D. thesis, Faculty of Agriculture, Cairo University, Cairo, Egypt. 301 pp.

Akman, K. \& Zumroglu, A. 1978. Effects of gamma radiation on the immature pupae of the Mediterranean fruit fly, Ceratitis capitata (Wied.): Dose response of laboratory reared and wild strain. Turkiye Bitki Koruma Dergisi 2(1): 37.

Alexandroy, D.A., Lapidus, I.L., Alexandroya, M.V., Korablinova, S.V. \& Levkovich, N.V. 1998. Rapid screening of spontaneous and radiation induced structural changes at the vestigial gene of Drosophila melanogaster by polymerase chain reaction. J. of Rapid Community 66: 33-38.

Atienzar, F.A., Cheung, V.V., Jha, A.N. \& Depledge, M.H. 2001. Fitness parameters and DNA effects are sensitive indicators of copper induced toxicity in Daphnia manga. Toxicol. Sci. 59: 241-250.

Black, W.C., Du Teau, N.M., Puterka, G.J., Nechols, J.R. \& Pettorini, J.M. 1992. Use of the random amplified polymorphic DNA polymerase chain reaction (RAPD PCR) to detect DNA polymorphisms in aphids (Homoptera: Aphididae). Bull. of Entomol. Res.82(2): 151-159.

Calkins, C.O. \& Parker, A.G. 2005. Sterile insect quality. In: Dyck, V.A., Hendrichs, J. \& Robinson, A.S. (Eds) Sterile Insect Technique: Principles and Practice in Area-Wide Integrated Pest Management. Springer, Dordrecht, The Netherlands. 269-296.

Egypt. 1 pp.

El-Ghawabi, A. 1928. The Mediterranean fruit fly, Ceratitis capitata. Agricultural New Annals Series, Ministry of Agriculture, Cairo, Egypt. 111-136

El-Sayed, T.S. 2013. Inherited sterility in the cotton leaf worm Spodoptera littoralis, (Boisd.), and changes in the DNA pattern as a result of using gamma radiation. Ph.D. thesis, Faculty of Science Ain Shams University, Cairo, Egypt. 216-219.

Enan, M.R. 2006. Application of random amplified polymorphic DNA to detect genotoxic effect of heavy metals. Biotech. and Appl. Bioch. 43: 147-154.

Enkerlin, W.R. 2005. Impact of fruit fly control programmes using the sterile insect technique. In: Dyck, V.A., Hendrichs, J. \& Robinson, A.S.(Eds) Sterile Insect Technique: Principles and Practice in Area-Wide Integ. Pest Manag.. Springer, Dordrecht, The Netherlands 651-676.

Ercan, F.S. 2015. Use of random amplified polymorphic DNA (RAPD) to detect DNA damage induced by Prangos ferulacea (Umbelliferae) essential oil against the Mediterranean flour moth Ephestia kuehniella (Lepidoptera: Pyralidae). Architecture of Biol.Sci. 67: 235-239.

Figueroa, I.A. 2018. The invasive Mediterranean fruit fly Ceratitis capitata Wied. (Diptera; Tephritidae): life history, ecology, behaviour and its implication in ethological management. (Introductory paper at The Faculty of Landscape Architecture, Horticulture and Crop Production Science 2).

Hall, E.J. \& Giaccia, E. 2006. Radiobiology for the Radiologist, $6^{\text {th }}$ edition. Lippincott, Wilkins and Williams Philadelphia, U.S.A.

Hamed, M. S., Salama, M. S., Salem, H., Abbassy, S. A. \& Zaghloul, Y. S. 2009. Sterility and associated molecular characteristics in male Callosobruchus maculatus. J. of Rad. Res. and Appl. Sci. 2: 563-575.

Hamza, A. F. 2007. Biological and biochemical studies on onion bulb fly Eumerus amoenus Loew as affected by gamma radiation. M.Sc. thesis. Faculty of Agriculture, El-Azhar University, Cairo, Egypt.

Hendrichs, J., Kenmore, P., Robinson, A.S. \& Vreysen, M.J.B. 2007. Area-wide integrated pest management (AW-IPM): Principles, practice and prospects. In: Vreysen, M.J.B., 
Robinson, A.S. \& Hendrichs, J. (Eds) Area-Wide Control of Insect Pests: From Research to Field Implementation. Springer, Dortrecht, The Netherlands. 3-33.

Ibrahim, S.M. \& El-Naggar, E.M.S. 2001. Radiation-induced change in mating and reproductive potential of the cotton leaf worm, Spodoptera littoralis. (Boisd.). Arab. J. of Nucl. Sci. and Appl. 34(1): 245-253.

Katiyar, K. P. \& Valerio, J. 1964. Further studies on the possible use of sterile male release technique in controlling or eradicating the Mediterranean fruit fly, Ceratitis capitata Wied. from Central America. Fifth International American Symposium on Peaceful Application of Nuclear Energy, Valpariaso (9-12 March 1964). 197.

Kinipling, Ef. 1955. Possibilities of insect control or eradication through the use of sexually sterile males. J. of Econ. Entomol. 48(3): 459-462.

Lea, D.E., 1956. Actions of Radiations on Living Cells, 2nd edition, Cambridge University Press, Cambridge. U.K.

Liquido, N. J.; Shinoda, L. A. \& Cunningham, R. T. 1991. Host plants of the Mediterranean fruit fly, Ceratitis capitata, an annotated world review. Ann. of the Entomol. Soc. of Amer. 77: 1-52.

O’brien, R.D. \& Wolfe, L.S. 1964. Radiation, Radioactivity and Insects. Academic Press, New York, U.S.A.

Rizk, S.A. Abdalla, R.S. \& Sayed, R.M. 2017. Changes occurred in the testes and DNA pattern of males wax moth Galleria mellonella first generation as a result of irradiation of their parents. Bull. of Entomol. Res. 107: 493-498.

Robinson, A.S. 2002. Mutations and their use in insect control. Rev. in Mutation Res. 511: $113-132$.

Savva, D., 1998. Use of DNA fingerprinting to detect genotoxic effects. Ecotoxicol. Environ. Safety 41:103-106.

Tanaka, N., Steiner, L. F., Ohinata, K. \& Okamoto, R. 1969. Low-cost larval rearing medium for mass production of oriental and Mediterranean fruit flies, J. of Econ. Entomol.62(4): 967-968.

Toppzada, A.A, Abdallah, S.S. \& El-Defrawi, M.F. 1966. Chemosterilization of larvae and adults of the Egyptian cotton leafworm, Prodenia littura by apholate, metepa and tepa. J. Econ. Entomol. 59: 1125-1128.

Von Sonttag, C. 1987. New aspects in the free-radical chemistry of pyrimidine nucleobases. Free Radical Research Community 2: 217-224.

Williams, J. G. K., Kubellk, A. R., Livak, K. J., Rafalaski, J. A. \& Tingey, S. V. 1990. DNA polymorphisms amplified by arbitrary primers are useful as genetic markers. Nucl. Acids Res. 18: 6231-6235.

Yang, X S. \&. Quiros, C.F 1993. Identification and classification of celery cultivars with RAPD markers. Theor. and Appl.Genet. 86:205-212.

Zaghloul, Y.S., Abbasy, S. \& Mansour, W., 2006. Variations induced to the DNA pattern of the hump of the hump beetle Gibium psylloides treated with gamma rays. Isotope Rad. Res. 38: 1347-1353.

Zahran, N.F., Hamza, A.F. \& Sayed, R.M. 2017. Evaluation of changes in genetic characteristics of male peach fruit fly, Bactrocera zonata irradiated with gamma radiation using RAPD-PCR technique. Pakis. J. of Zool. 49(3): 951-956. 


\section{ARABIC SUMMARY}

تغيرات المؤشرات الحيوية المستحثة في ذبابة ثمار البحر المتوسط ، المعاملة بالجرعات المعقمة وتحت المعقمة من أشعة جاما

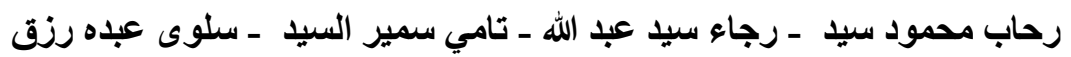

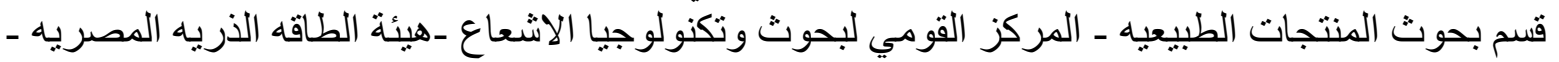

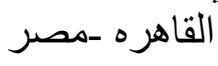

تستخدم تقنية الإشعاع على نطاق واسع لإنتاج تغييرات في النظم البيولوجية. الهُف من هذا العمل هو تحديد التباين

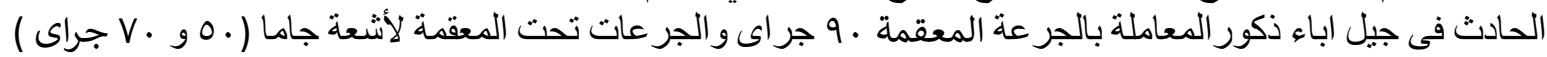

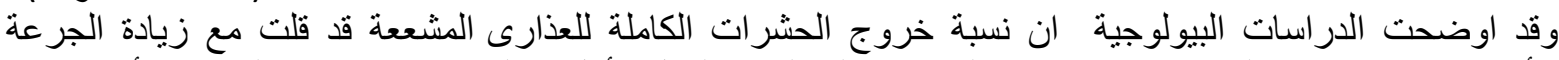

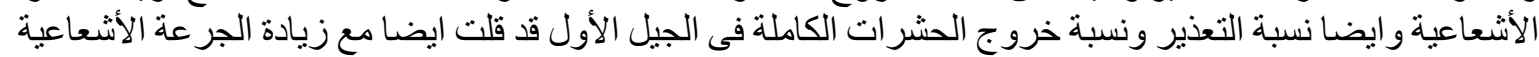

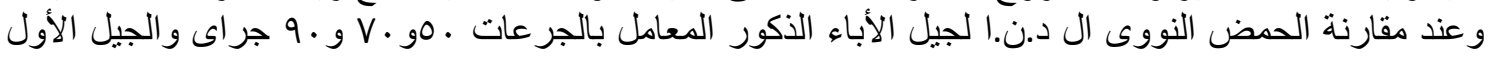

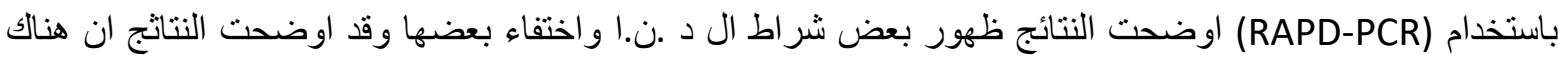
اختلافات بين الأباء المشععة با لجرعات (

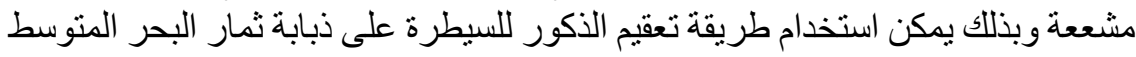

